the uterine exploration setting up a slight endometritis, the discharge from which for some reasons had been partially retained, and there never was any suspicion of abscess formation. Up to the time of this discharge the lochia had diminished in quantity though they had not ceased entirely. About this time also the veins of the right leg became infected. From the $8 \mathrm{th}$ to the 20th the temperature remained between $99^{\circ}$ and $100^{\circ}$ and the pulse from 100 to 112 . On the 12th I gave ether and opened a large abscess in the left thigh. On the 15th I opened another in the right calf and on the 17th one in the left calf. For the next four days the temperature fluctuated slightly, about $100^{\circ}$, but on the 24 th it went up to $103^{\circ}$, with a pulse of 120 . I again gave ether and thoroughly opened up the abscesses and inserted drainage tubes. On the next day the temperature had fallen to normal, where it has since remained. The wounds in the legs are fast healing, the tubes having been removed. The patient is free from pain, has a good appetite, and sleeps well, being carried downstairs daily to lie on a couch. I continued the liquor ferri perchloridi throughout the illness every three hours, with the addition for the first ten days of five-minim doses of liquor strychninæ hydrochloridi every four hours. The patient had no trouble with her bowels, as they were moved every day, salts only being required on two occasions. There was no tendency to diarrhœea. There is now no morbid uterine discharge. The patient menstruated last week.

Camborne.

\section{A CASE OF EMPHYSEMA OCCURRING DURING PARTURITION.}

By Francis H. Sprague, M.R.C.S. Eng., L.R.C.P. Lond.

CASES of emphysema occurring during labour are apparently not common and the text-books I have at hand make only a passing reference to the possibility of its being a complication of labour; the effusion of air into the connective-tissue spaces is the result of rupture of some of the air vesicles of the lungs due to the excessive straining caused by the violent labour pains. The following notes of a case recently under my care may be worth publishing.

The patient was a perfectly healthy primipara, aged 24 years. The presentation of the child was normal-namely, in the left occipito-anterior position. Labour was somewhat prolonged owing to the fact that the total quantity of liquor amnii was very small and there was no dilating bag of waters in front of the child's head. With the descent of the head into the vagina the pains became very violent and throughout the second stage chloroform was administered in a quantity which, although sufficient to render the patient unconscious of what she was enduring, did not prove sufficient to prevent the rupture of the pulmonary tissue and subsequent emphysema. As soon as the head began to distend the perineum the patient was fairly under the influence of the anæsthetic and I gave my attention to the delivery of the child. It was now for the first time noticed that the right side of the mother's face and neck was swollen. When the labour was completed the swelling of the face, together with congestion of the conjunctivæ, was sufficient to make one anxious. On examination the swollen area extended over the whole front of the chest on the right side down to the fourth rib; the supraclavicular fossa was distended and also the anterior and posterior triangles of the neck; the right side of the face was puffy and the conjunctiva was injected. On palpation the characteristic crackling sensation caused by air in the connective tissue could be felt over the whole area. The voice was practically lost, the patient being only able to speak in a husky whisper. Difficulty of breathing and difficulty of swallowing were both marked, the patient repeatedly complaining that she felt as if choking. For the first 24 hours these symptoms caused the greatest discomfort. There was no vomiting after the anæsthetic, although severe headache and rise of temperature occurred during the first two days. Then all the symptoms subsided, the voice returned, and the dysphagia and choking sensation disappeared. The emphysema began to clear up. By the eighth day all the air had become absorbed and examination of the chest wall and lungs then revealed no abnormal signs.

Beyond the initial discomfort and the anxiety the patient felt concerning the condition it did not interfere with the progress of the puerperium. No treatment was adopted beyond protecting the chest and neck with cotton wool, the patient being kept absolutely quiet and told to restrain any cough or other respiratory effort. An aperient of calomel was given on the second day, its action being assisted by a soap-and-water enema.

Gloucester.

\section{A athitror}

\section{HOSPITAL PRACTIOE, BRITISH AND FOREIGN.}

Nulla autem est alia pro certo noscendi via, nisi quamplurimas et morborum et dissectionum historias, tum aliorum tum proprias collectas habere, et inter se comparare.-MoRGAGNI De Sed. et Caus. Morb., lib. iv., Procmium.

\section{ANDOVER COTTAGE HOSPITAL.}

A CASE OF PERFORATED GASTRIC ULCER WITH SOME ANOMALOUS FEATURES SUCCESSFULLY TREATED BY EARLY OPERATION.

(Under the care of Mr. E. A. FARR.)

ON May 20th, 1905, Mr. Farr's assistant (Mr. K. F. Gordon) was called to a case which afforded all the symptoms of mild catarrhal appendicitis, and though the patient (a frail-looking anæmic girl, aged 20 years) said that she had been treated previously for anæmia and ulceration of the stomach he was unable to attribute her then symptoms to that organ. Pain and tenderness were confined to the right iliac region and were especially referred to McBurney's spot. The attack yielded to the usual palliative treatment for appendicitis and the patient was subsequently treated for chlorosis and three weeks after the attack resumed her occupation.

On the evening of July 16th, about 6.30, Mr. Gordon was called to see the same patient who, whilst returning from an afternoon walk, had been suddenly seized with severe abdominal pain. As Mr. Farr was close at hand Mr. Gordon called him in and they found the patient pallid and collapsed; the abdomen was rigid and tender and there was undoubted dulness over the right iliac fossa. While at first the patient asserted that the pain was mainly in that region she afterwards referred it to the umbilical and epigastric regions. She vomited twice after the onset of the pain. Hot fomentations were applied at once and one-sixth of a grain of morphine was given to relieve the pain, and arrange ments were immediately made for the removal of the patient to the Andover Cottage Hospital for the operation which was deemed imperative. On being moved the patient again vomited some blood-stained matter and this inclined $\mathrm{Mr}$. Farr and Mr. Gordon to diagnose the lesion as a gastric one, though in view of the recent attack of appendicitis and the present symptoms they could scarcely overlook the possibility of a perforated appendix.

At 10 P.M. Dr. Gordon administered the anæsthetic (gas. ether, and A.C.E. mixture being employed) and Mr. Farr was able to make a further examination of the patient's abdomen. Even under anæsthesia rigidity of the epigastrium persisted while it disappeared elsewhere; there was still dulress over the right iliac fossa while resonance verging on tympanites prevailed over the rest of the abdomen and to some extent replaced the liver dulness. Mr. Farr decided to explore the iliac fossa first as he thought that if the appendix were at fault it would be ccmparatively easy to repair the disaster. On making the usual incision for appendectomy a quantity of discoloured serous fluid (sufficient to account for the dulness) escaped from the wound. This fluid contained some recent ingesta. 'The appendix was found to be intact but partially adherent to the wall of the fossa, evidently the consequence of a little plastic peritonitis occurring at the time of the attack of appendicitis recorded above. These adhesions broke down readily and the appendix was amputated, as this could be done rapidly and the patient's condition was giving no anxiety. Portions of the intestines that presented at the wound were swabbed with saline solution and a drainage-tube was inserted before closing the incision. By this preliminary operation the diagnosis was established, the patient was secured against further attacks of appendicitis, and a drainage outlet was provided which 